\title{
Efektifitas Penginduksi Resistensi dan Biopestisida terhadap Penyakit Bercak Daun Cercospora dan Antraknosa pada Cabai (Capsicum annuum L.)
}

\author{
DOI 10.18196/pt.2014.030.106-114
}

\author{
Bambang Heri Isnawan* dan Khusnul Mubarok \\ Program Studi Agroteknologi, Fakultas Pertanian, Universitas Muhammadiyah Yogyakarta, \\ Jl. Lingkar Selatan, Kasihan, Bantul, Yogyakarta 55183, Indonesia Telp. 0274387656 , \\ *Corresponding author, e-mail: bambang_hi@yahoo.com
}

\begin{abstract}
ABSTRAK
Penelitian ini bertujuan untuk mengetahui sumber daya hayati potensial dalam bentuk agen hayati penginduksi resistensi dan biopestisida serta kombinasinya dalam mengendalikan penyakit bercak daun Cercospora sp. dan antraknosa pada cabai. Metode penelitian yang digunakan adalah Metode Percobaan Lapangan yang menggunakan rancangan faktorial 3 x 5 yang disusun dengan rancangan acak kelompok lengkap (RAKL) dengan 3 ulangan sebagai blok. Faktor pertama yaitu penginduksi resistensi, dengan 3 aras yaitu non penginduksi resistensi, penginduksi resistensi dari Mirabilis jalapa (bunga pukul empat/ sore) dan penginduksi resistensi dari Amaranthus spinosus (bayam duri). Faktor kedua yaitu biopestisida, dengan 5 aras yaitu non biopestisida, biopestisida formula Amp, biopestisida Pfm001, biopestisida formula Amp + Pfm001 dan fungisida kimia sintetis. Hasil penelitian menunjukkan bahwa penginduksi resistensi dapat menekan buah cabai terserang antraknosa tetapi tidak berpengaruh dalam menekan penyakit bercak daun Cercospora, penginduksi resistensi tidak mempengaruhi pertumbuhan tanaman tetapi dapat menekan jumlah buah sakit dan berat buah sakit, penginduksi resistensi berupa Mirabilis jalapa dan Amaranthus spinosus dapat menekan antraknosa buah cabai, biopestisida tidak berpengaruh terhadap penyakit bercak daun Cercospora tetapi menurunkan Antraknosa pada buah cabai, biopestisida tidak berpengaruh terhadap pertumbuhan tanaman cabai tetapi dapat menurunkan jumlah buah sakit dan berat buah sakit serta dapat meningkatkan hasil. Tidak terdapat interaksi antara penginduksi resistensi dan biopestisida terhadap semua parameter kecuali terhadap parameter Area Under Desease Progress Curve (AUDPC).

Kata kunci: Sistem penginduksi resistensi, Bio pestisida, Bercak daun Cercospora, Antraknosa, Cabai
\end{abstract}

\begin{abstract}
A research to confirm potential natural resources as an induced systemic resistance agent and bio- pesticide and it combination against Cercospora leaf spot and anthracnose on pepper. The research method was conducted by experiment on field, arranged in factorial design $3 \times 5$, arranged Randomized Completely Block Design with three replications as blocks. The First factor was inducer of resistance, consist of 3 levels i.e. non-inducer of resistance, inducer of resistance by Mirabilis jalapa and inducer of resistance by Amaranthus spinosus. The Second factor was bio-pesticide consist of 5 level i.e. non-bio-pesticide, bio-pesticide Amp, bio-pesticide Pfm001, bio-pesticide Amp+Pfm001 and chemical fungicide. The result of this research showed that inducer of resistance could suppressing damage fruit by anthracnose but could not influencing in Cercospora leafspot. Inducer of resistance could not be influencing growth of plant but could suppressing damage fruit volume and total damage fruit. Inducer of resistance i.e. Mirabilis jalapa and Amaranthus spinosus could suppressing damage fruit by anthracnose. Bio-pesticide could not be influencing in Cercospora leafspot but could suppressing anthracnose on pepper. Bio-pesticide could not be influencing the growth of pepper but could suppressing total damage fruit and damage fruit volume also increasing up the yield. There is no interaction between inducer of resistance and bio-pesticide through every parameter except for the area under diseases progress curve (AUDPC)

Keywords: Systemic induced resistance, Bio-pesticide, Cercospora leafspot, Anthracnose, Pepper
\end{abstract}

\section{PENDAHULUAN}

Di Indonesia cabai merah (Capsicum annuum L.) merupakan komoditas sayuran penting dilihat dari luas lahan produksi maupun nilainya. Cabai merupakan tanaman yang memiliki daya adaptasi tinggi, sehingga lokasi produksinya tersebar luas di daerah dataran rendah maupun dataran tinggi Indonesia (Indratmi, 2002).
Cabai merupakan salah satu komoditi hortikultura dari kelompok sayuran yang menjadi tanaman unggulan. Cabai juga dapat dikategorikan sebagai komoditas komersial karena sebagian besar ditujukan guna memenuhi permintaan pasar. Karakteristik pengembangannya memungkinkan komoditas tersebut dikonsumsi 
dalam bentuk segar maupun olahan (Adiyoga, 1995; BPS, 2000).

Rata-rata hasil panen cabai merah pada tahun 2002 tercatat sebesar 1,8 ton/ha (BPS, 2002) dan pada tahun 2003 tercatat 5,3 ton/ha (BPS, 2003). Angka tersebut masih rendah bila dibandingkan dengan potensi produksinya yang dapat mencapai 12 ton/ha (Duriat, 1996 cit. Indratmi, 2002; Vos dan Duriat, 1994).

Hasil panen yang rendah terutama disebabkan oleh buruknya kesehatan tanaman akibat serangan hama dan penyebab penyakit. Anasir yang lain yaitu kualitas benih yang rendah, kurangnya pengetahuan petani tentang pemanfaatan teknologi yang tepat dapat merupakan hambatan bagi peningkatan produksi cabai (Vos dan Duriat, 1994).

Aspek kehilangan hasil akibat adanya serangan berbagai hama dan penyakit tanaman menjadi hal yang urgen. Hal ini dapat diketahui bahwa di Indonesia, khususnya di Jawa, diketahui bahwa kehilangan hasil oleh adanya penyakit bercak daun Cercospora pada cabai berkisar antara 30 - $40 \%$ demikian juga akibat penyakit antraknosa kehilangan hasil berkisar antara 21 - 63 \% bahkan dapat berlebih hingga 100 $\%$ apabila didukung oleh kondisi yang basah, banyak hujan, dan lembab (Ebenebe, 1980 cit. Hadisutrisno, 1999; Oka, 2001; Indratmi, 2002).

Dalam usaha meningkatkan produktivitas pertanian khususnya dalam pengendalian hama, penyakit serta gulma di pertanaman, cara-cara bercocok tanam klasik seperti penggunaan insektisida yang tidak selektif, clean farm dan pertanian monokultur adalah contoh umum dari praktik yang selama ini digunakan petani. Praktik-praktik tersebut ternyata memiliki kelemahan dan kerusakan terhadap keseimbangan ekosistem (Indrawati et al., 2000).

Untung (1993) menegaskan bahwa penggu- naan insektisida dapat menimbulkan dampak negatif, antara lain timbulnya resistensi hama, ledakan hama kedua, resurgensi atau peristiwa meningkatnya populasi hama setelah memperoleh perlakuan insektisida, terbunuhnya musuh alami, bahaya bagi kesehatan masyarakat dan ancaman pencemaran lingkungan.

Pendekatan secara terpadu dengan menggabungkan beberapa metode pengendalian, termasuk pengendalian hayati dengan menggunakan agens hayati (Soesanto, 2002), penggunaan musuh alami (Rosmana et al., 1997) dan perspektif baru berupa imunisasi tanaman (Suganda, 1999) sangat dianjurkan guna mencapai efektifitas yang lebih tinggi dalam mengendalikan suatu penyakit pada tanaman yaitu dengan menekan dan mengendalikan jamur patogen (Suwahyono dan Priyo, 1997).

Perkembangan baru dalam usaha melindungi tanaman dari serangan berbagai penyakit adalah Planimunization, suatu metode terkini yang dapat diupayakan guna menangani penyakit yang disebabkan oleh virus, bakteri, jamur maupun nematoda (Suganda, 1999).

Temuan-temuan ini akan merupakan alat penyeimbang bagi dilaksanakannya strategi PHT yang lebih berwawasan lingkungan, serta akan menjamin produk yang dihasilkannya aman bagi konsumen sehingga hal ini masih menjamin hakhak konsumen yang telah ditetapkan, yaitu hak atas kenyamanan, keamanan dalam mengkonsumsi barang atau jasa.

Dari pertimbangan tersebut di atas, diperlukan adanya suatu inovasi dari suatu invensi formula dengan senyawa bioaktif tanaman (neurotoksin), mengingat sangat luasnya kisaran keanekaragaman hayati yang bisa dieksploitasi.

Tujuan Penelitian adalah mengetahui sumber daya hayati potensial dalam bentuk agen hayati penginduksi resistensiresistensi dan biopestisida 
serta kombinasinya dalam mengendalikan penyakit bercak daun Cercospora capsici dan antraknosa pada cabai.

\section{BAHAN DAN METODE}

Penelitian ini dilaksanakan di Dusun Nglingi, Desa Harjobinangun, Kecamatan Pakem, Kabupaten Sleman, Provinsi Daerah Istimewa Yogyakarta, mempunyai ketinggian tempat $\pm 600 \mathrm{dpl}$, dengan kisaran suhu $22^{\circ} \mathrm{C}-32^{\circ} \mathrm{C}$ dan curah hujan $3764 \mathrm{~mm} /$ tahun.

Bahan-bahan yang digunakan dalam penelitian ini, terdiri dari pupuk kandang, pupuk urea, pupuk ZA, pupuk SP-36, pupuk KCl, pupuk NPK, Benih Cabai Var.TM99, bambu, mulsa plastik hitam perak dan tali rafia plastik. Ektrak Mirabilis jalapa (bunga pukul empat) dan Amaranthus spinosus (bayam duri), Biopestisida Amp, Biopestisida Pfm001, Fungisida Kimia Sintetik (Benzotiadhiazole + Mangkozeb 60 \%), Carborundum 600 mess, Alkohol 70\%, Larutan Buffer $25 \%$, Kapas steril. Alat-alat yang dipergunakan dalam penelitian ini adalah penggaris, Colony counter, luv, cangkul, sabit, bajak, sprayer, lumpang/mortir/alu, tabung reaksi, oven dan timbangan.

Metode percobaan lapangan menggunakan rancangan faktorial $3 \times 5$ yang disusun dengan rancangan acak kelompok lengkap (RAKL) dengan faktor pertama yaitu penginduksi resistensi dengan 3 aras yaitu non penginduksi resistensi, penginduksi resistensi dari Mirabilis jalapa (bunga pukul empat/sore), penginduksi resistensi dari Amaranthus spinosus (bayam duri). Faktor kedua yaitu biopestisida dengan 5 aras yaitu non biopestisida, biopestisida Formula Amp, biopestisida Pfm001, Biopestisida Formula Amp + Pfm001 dan fungisida kimia sintetis.

Pemberian perlakuan dengan bahan penginduksi resistensi menggunakan metode pelukaan pada daun (plant immunization). Ekstrak kedua penginduksi resistensi dioleskan di permukaan daun bagian atas pada saat persemaian, sedangkan pemberian biopestisida dengan penyemprotan secara berkala.

Pengamatan dilakukan terhadap perkembangan penyakit seperti intensitas serangan penyakit bercak daun Cercospora, persentase buah cabai terserang penyakit antraknosa, perkembangan penyakit dibawah kurva AUDPC (Area Under Desease Progress Curve). Pengamatan Terhadap pertumbuhan vegetatif Tanaman dilakukan terhadap tinggi tanaman, lebar kanopi, berat kering tanaman. Pengamatan terhadap produksi tanaman dilakukan terhadap berat buah sehat pertanaman, berat buah sakit pertanaman, berat buah pertanaman, jumlah buah sehat pertanaman, jumlah buah sakit pertanaman dan hasil tanaman.

Analisis data dilakukan dengan menggunakan sidik ragam (uji F) pada taraf $\alpha 5 \%$ dan apabila ada beda nyata dilanjutkan dengan uji Duncan (Duncan Multiple Range Test) dengan taraf $\alpha 5 \%$. Transformasi data dilakukan menggunakan transformasi Arc sin sesuai aturan transformasi data yang diuraikan oleh Gomez dan Gomez (1995).

\section{HASIL DAN PEMBAHASAN}

Rerata intensitas Cercospora menunjukkan bahwa Biopestisida Amp, Pfm001, Amp+Pfm001 tidak berpengaruh nyata terhadap intensitas serangan penyakit bercak daun bila dibandingkan dengan tanpa biopestisida (kontrol) dan fungisida kimia (Tabel 1). Perlakuan penginduksi resistensi juga tidak memberikan pengaruh yang nyata dalam menekan intensitas Cercospora. Interaksi juga tidak didapatkan antara perlakuan penginduksi resistensi dan biopestisdia. 
Tabel 1. Rerata Intensitas Serkospora, Persentase Buah Sakit Antraknosa

\begin{tabular}{lcc}
\hline \multicolumn{1}{c}{ Perlakuan } & Intensitas Cercospora & \% Buah Sakit Antraknosa \\
\hline Penginduksi & & \\
Tanpa penginduksi & $21.07 \mathrm{p}$ & $6.07 \mathrm{p}$ \\
Mirabilis jalapa & $19.60 \mathrm{p}$ & $4.57 \mathrm{q}$ \\
Amaranthus spinosus & $19.47 \mathrm{p}$ & $4.19 \mathrm{q}$ \\
Biopestisida & & \\
Tanpa Biopestisida & $21.33 \mathrm{a}$ & $6.27 \mathrm{a}$ \\
Bio Amp & $20.67 \mathrm{a}$ & $4.47 \mathrm{~b}$ \\
Bio Pfm001 & $19.33 \mathrm{a}$ & $5.49 \mathrm{ab}$ \\
BioAmp+Pfm & $19.56 \mathrm{a}$ & $4.53 \mathrm{~b}$ \\
Fungisida kimia & $19.33 \mathrm{a}$ & $3.95 \mathrm{~b}$ \\
\hline Interaksi & - & - \\
\hline Keterangan: Angka yang diikuti huruf pada kolom yang sama tidak berbeda nyata menurut
\end{tabular}

uji DMRT pada taraf $\alpha 5 \%$. Tanda (-) menunjukkan tidak ada interaksi.

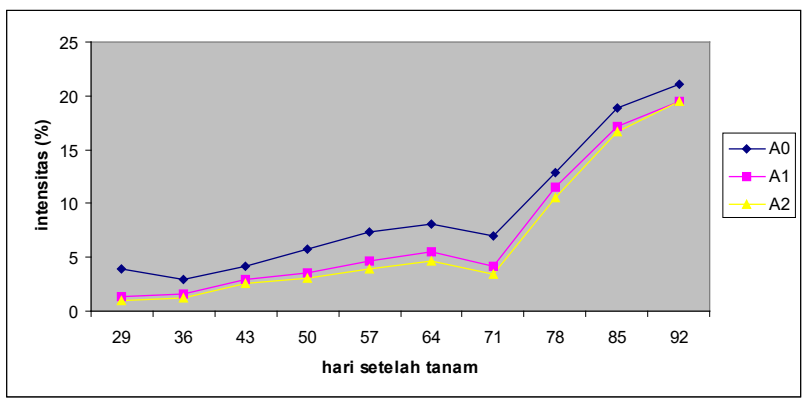

Gambar 1. Grafik Pengaruh Biopestisida terhadap Intensitas Bercak Daun Cercospora

Keterangan:

$\mathrm{A} 0=$ non penginduksi resistensi.

A1 = penginduksi resistensi Mirabilis jalapa.

$\mathrm{A} 2$ = penginduksi resistensi Amaranthus spinosus.

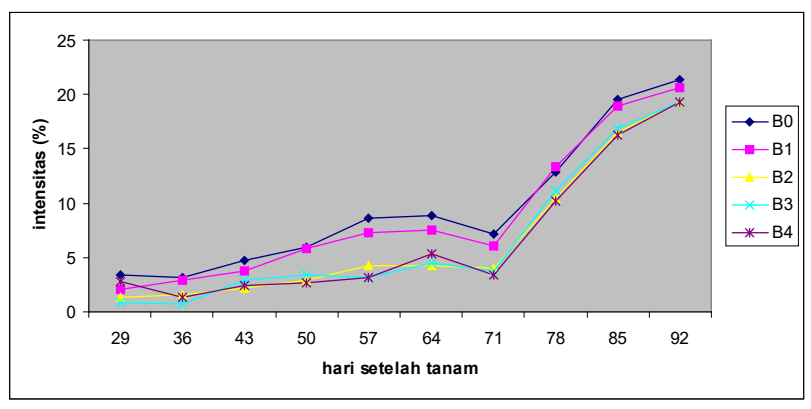

Gambar 2. Grafik Pengaruh Biopestisida terhadap Intensitas Bercak Daun Cercospora

Keterangan:

$\mathrm{BO}=$ non biopestisida $\quad \mathrm{B} 3=$ biopestiosida $\mathrm{Amp}+\mathrm{Pfm} 001$

$\mathrm{B1}=$ biopestisida Amp

$\mathrm{B} 2$ = biopestisida Pfm00 $B 4=$ fungisida kimia

Gambar 1 menunujukan Pengaruh penginduksi resistensi terhadap intensitas bercak daun akibat Mirabilis jalapa dan Amaranthus spinosus lebih rendah dari non penginduksi resistensi. Peningkatan terjadi mulai umur 29 hst dan paling tinggi pada 64 hst, kemudian pada umur 64 hst hingga 71 hst intensitas serangan menurun secara keseluruhan, lalu mulai 71 hst hingga 92 hst intensitas serangan meningkat.

Gambar 2 menunujukkan Pengaruh biopestisida terhadap intensitas bercak daun pada cabai semakin meningkat yaitu mulai umur 29 hst hingga tertinggi umur 64 hst, setelah itu terjadi penurunan intensitas serangan bercak daun pada umur 71 hst yang lebih rendah dari intensitas umur 64 hst, kemudian intensitas serangan meningkat pada umur 78 hst hingga 92 hst. Pada 36 hst hingga 92 hst perlakuan menggunakan biopestisida Pfm001, kombinasi biopestisida Amp+Pfm001 dan fungisida kimia kecenderungan lebih rendah dari biopestisida Amp dan non biopestisida. Intensitas serangan bercak daun yang didapatkan pada perlakuan non biopestisida paling tinggi pada umur 43 hst, 57 hst, 64 hst, 71 hst, 85 hst, dan 92 hst.

Penurunan intensitas serangan bercak daun pada umur 71 hst dimungkinkan karena adanya peningkatan pertumbuhan vegetatif pada tanaman cabai khususnya daun cabai pada 64 hst sehingga berpengaruh terhadap penurunan skoring kategori serangannya dan menyebabkan penurunan intensitas penyakit pada 71 hst (Suganda, 1999; Martanto et.al., 2003).

Hasil sidik ragam yang ditunjukkan pada Tabel 1, persentase buah sakit terserang antraknosa menunjukkan ada beda nyata pada perlakuan, baik perlakuan penginduksi resistensi maupun biopestisida yang dicobakan, tidak demikian dengan antar perlakuan penginduksi resistensi dan biopestisida tidak menunjukkan interaksi nyata pada faktor yang dicobakan. Perlakuan biopestisida Amp, biopestisida Amp+Pfm001 
dan fungisida kimia berpengaruh nyata menurunkan persentase buah cabai terserang penyakit antraknosa dibanding dengan perlakuan tanpa biopestisida. Sedangkan pada perlakuan menggunakan penginduksi, penggunaan penginduksi resistensi Amaranthus spinosus dan Mirabilis jalapa berpengaruh nyata menurunkan persentase buah terserang antraknosa pada cabai dibanding dengan perlakuan tanpa penginduksi.

Efektifitas perlakuan penginduksi resistensi dan biopestisida dalam menekan intensitas serangan bercak daun Cercospora dan perkembangan penyakit antraknosa sangat dipengaruhi oleh adanya ketahanan terinduksi pada tanaman cabai akibat perlakuan yang dicobakan. Beberapa hal diantaranya adalah adanya akumulasi senyawa bioaktif neurotoksin yang terpacu pada tanaman cabai. Senyawa asam salisilat (salisilat acid), pathogen relathed protein (PR-protein) merupakan senyawa yang sangat berperan dalam ketahanan terinduksi pada tanaman (Hersanti, 2003).

Tabel 2. Perkembangan Penyakit di Bawah Kurva (AUDPC) dan Persentase Penghambatan (\%)

\begin{tabular}{lcc}
\hline \multicolumn{1}{c}{ Perlakuan } & AUDPC & Penghambatan (\%) \\
\hline Tanpa penginduksi, tanpa biopestisida & $711.67 \mathrm{a}$ & $0.00 \mathrm{a}$ \\
Tanpa penginduksi resistensi+ Amp & $595.00 \mathrm{~b}$ & $16.39 \mathrm{~b}$ \\
Tanpa penginduksi resistensi+ Pfm 001 & $599.67 \mathrm{~b}$ & $15.73 \mathrm{~b}$ \\
Tanpa penginduksi resistensi+ Amp + Pfm 001 & $434.00 \mathrm{cdefg}$ & $39.01 \mathrm{cdefg}$ \\
Tanpa penginduksi resistensi+ fungisida kimia & 417.67 defgh & $41.31 \mathrm{defgh}$ \\
Mirabilis jalapa, Tanpa biopestisida & $546.00 \mathrm{cb}$ & $23.27 \mathrm{cb}$ \\
Mirabilis jalapa + Amp & $539.00 \mathrm{bcd}$ & $24.26 \mathrm{bcd}$ \\
Mirabilis jalapa + Pfm001 & $301.00 \mathrm{hi}$ & $57.70 \mathrm{hi}$ \\
Mirabilis jalapa + Amp + Pfm001 & 396.67 efghi & $44.26 \mathrm{efghi}$ \\
Mirabilis jalapa + Fungisida kimia & 371.00 efghi & $47.87 \mathrm{efghi}$ \\
Amaranthus sp, Tanpa biopestisida & $490.00 \mathrm{bcde}$ & $31.14 \mathrm{bcde}$ \\
Amaranthus sp + Amp & $476.00 \mathrm{bcdef}$ & $33.11 \mathrm{bcdef}$ \\
Amaranthus sp + Pfm001 & $282.33 \mathrm{i}$ & $60.33 \mathrm{i}$ \\
Amaranthus sp + Amp + Pfm001 & $354.67 \mathrm{fghi}$ & $50.16 \mathrm{fghi}$ \\
Amaranthus sp + Fungisida kimia & $331.33 \mathrm{ghi}$ & $53.44 \mathrm{ghi}$ \\
\hline Interaksi & + & + \\
\hline Keterangan: Angka yang diikuti huruf pada kolom yang sama tidak berbeda nyata menurut \\
uji DMRT pada taraf $\alpha$ \% . Tanda (+) menunjukkan ada interaksi. &
\end{tabular}

Hasil sidik ragam pada perkembangan penyakit di bawah kurva AUDPC (Area Uder Desease Progress Curve) pada tabel 2 menunjukkan ada beda nyata pada perlakuan penginduksi resistensi dan biopestisida, demikian juga dengan antar perlakuan penginduksi resistensi dan biopestisida menunjukkan interaksi. Jika nilai AUDPC perlakuan semakin kecil, maka efisiensi penghambatannya semakin besar terhadap intensitas serangan Cercospora. AUDPC yang terbaik didapatkan pada kombinasi penginduksi resistensi Amaranthus spinosus dan biopestisida Pfm001, meskipun tidak berbeda dengan beberapa kombinasi yaitu Mirabilis jalapa dan Pfm001, Amaranthus spinosus dan fungisida kimia, Amaranthus spinosus dan Amp+Pfm001, Mirabilis jalapa dan fungisida kimia, serta dengan Mirabilis jalapa dan Amp+Pfm001.

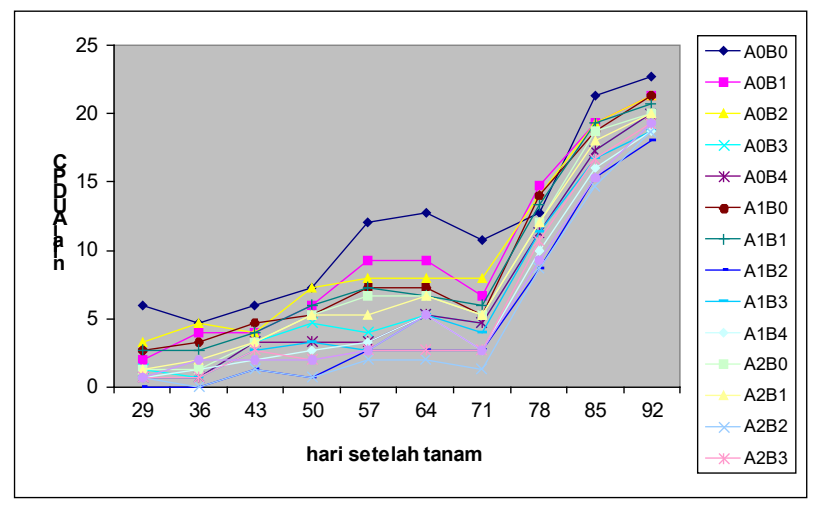

Gambar 3. Pengaruh Penginduksi Resistensi dan Biopestisida pada AUDPC

\section{Keterangan:}

$\mathrm{A} 0=$ non penginduksi resistensi

A1 = penginduksi resistensi Mirabilis jalapa.

A2 = penginduksi resistensi Amaranthus spinosus $\mathrm{BO}=$ non biopestisida

B1 $=$ biopestisida Amp

B2 = biopestisida Pfm001

$\mathrm{B} 3=$ biopestiosida Amp +Pfm001 $\mathrm{B} 4=$ fungisida kimia

(A0B0) menurun pada 29 hst hingga 36 hst, lalu meningkat pada 36 hst hingga 64 hst paling tinggi, kemudian penurunan terjadi lagi pada 71 hst, kemudian meningkat lagi hingga 92 hst. Demikian juga untuk perlakuan selain AOBO diatas terlihat bahwa secara umum pada 29 hst hingga 64 hst meningkat, lalu pada 64 hst hingga 
71 hst menurun, kemudian 71 hst hingga 92 hst meningkat kembali. Pada umur 36 hst, 50 hst, 57 hst, 64 hst, 71 hst terlihat bahwa perlakuan Amaranthus spinosus+biopestisida Pfm001 (A2B2) paling rendah nilainya.

Tabel 2 menunjukkan bahwa persentase penghambatan yang terbaik didapatkan pada penginduksi resistensi Amaranthus spinosus dan biopestisida Pfm001 dengan nilai persentase penghambatan 60,33\%, meskipun tidak berbeda dengan beberapa perlakuan yaitu penginduksi resistensi Mirabilis jalapa dan biopestisida Pfm001, penginduksi resistensi Amaranthus spinosus dan fungisida kimia, penginduksi resistensi Amaranthus spinosus dan biopestisida Amp+Pfm001, penginduksi resistensi Mirabilis jalapa dan fungisida kimia, penginduksi resistensi Mirabilis jalapa dan biopestisida Amp+Pfm001. Nilai tersebut diatas lebih tinggi dibandingkan dengan perlakuan tanpa penginduksi resistensi dan fungisida kimia dengan persentase sebesar 41,31 \%. Sedangkan kombinasi bahan penginduksi resistensi dengan Pfm001, kombinasi penginduksi resistensi dengan biopestisida Amp+Pfm001, dan kombinasi penginduksi resistensi dengan fungisida kimia efektif dalam menghambat perkembangan cendawan Cercospora capsici pada cabai. Bahan penginduksi resistensi baik Mirabilis jalapa dan Amaranthus spinosus dan biopestisida Pfm001 (Peudomonas fluorescence) dan biopestisida Amp (bahan aktif Dioscorea sp) tersebut efektif merangsang ketahanan sistemik pada tanaman cabai terhadap serangan cendawan Cercospora sp. Hasil percobaan tersebut sesuai dengan penelitian sebelumnya yang telah dilakukan oleh Hersanti (2003) bahwa ekstrak Mirabilis jalapa dan Amaranthus spinosus dapat meningkatkan ketahanan tanaman cabai terhadap penyakit dan oleh Oka (2001) yang menjelaskan bahwa bakteri Pseudomonas strain fluorescence dapat menekan perkembangan penyakit akibat jamur Colletotricum capsici.
Tabel 3. Rerata Tinggi tanaman (cm), Lebar kanopi (cm) dan Berat kering tanaman (gram)

\begin{tabular}{lccc}
\hline \multicolumn{1}{c}{ Perlakuan } & Tinggi tanaman & Lebar kanopi & Berat Kering \\
\hline Penginduksi & & & \\
Tanpa penginduksi & $72.67 \mathrm{p}$ & $57.61 \mathrm{p}$ & $103.30 \mathrm{p}$ \\
Mirabilis jalapa & $73.05 \mathrm{p}$ & $59.08 \mathrm{p}$ & $101.94 \mathrm{p}$ \\
Amaranthus spinosus & $71.33 \mathrm{p}$ & $58.00 \mathrm{p}$ & $108.05 \mathrm{p}$ \\
Biopestisida & & & \\
Tanpa Biopestisida & $73.74 \mathrm{a}$ & $59.36 \mathrm{a}$ & $108.54 \mathrm{a}$ \\
Bio Amp & $73.47 \mathrm{a}$ & $60.08 \mathrm{a}$ & $103.77 \mathrm{a}$ \\
Bio Pfm001 & $72.40 \mathrm{a}$ & $58.13 \mathrm{a}$ & $94.89 \mathrm{a}$ \\
BioAmp+Pfm & $71.74 \mathrm{a}$ & $57.93 \mathrm{a}$ & $113.22 \mathrm{a}$ \\
Fungisida kimia & $70.41 \mathrm{a}$ & $55.67 \mathrm{a}$ & $101.74 \mathrm{a}$ \\
\hline Interaksi & - & - & - \\
\hline
\end{tabular}

Keterangan: Angka yang diikuti huruf pada kolom yang sama tidak berbeda nyata menurut uji DMRT pada taraf $\alpha 5 \%$. Tanda (-) menunjukkan tidak ada interaksi.

Hasil sidik ragam tinggi tanaman, lebar kanopi dan berat kering tanaman seperti yang ditunjukkan pada tabel 3 menunjukkan tidak berbeda nyata pada perlakuan penginduksi resistensi maupun biopestisida yang dicobakan, demikian juga dengan antar perlakuan penginduksi resistensi dan biopestisida tidak menunjukkan interaksi nyata pada faktor yang dicobakan.

Kondisi tanaman yang sehat, bebas dari serangan organisme pengganggu tanaman baik penyakit maupun hama akan berpengaruh terhadap pertumbuhan tanaman yang baik dilapangan. Sedangkan apabila kondisi tanaman ternyata banyak terserang OPT maka kecenderungan akan berpengaruh terhadap pertumbuhan dan perkembangan tanaman (Untung, 1993).

Tabel 4 menunjukkan bahwa penginduksi resistensi Mirabilis jalapa dan Amaranthus spinosus dapat meningkatkan berat buah buah sehat dan berat buah pertanaman pada tanaman cabai. Biopestisida Amp, Pfm001, Amp+Pfm001 tidak berpengaruh nyata terhadap berat buah sehat bila dibandingkan dengan non biopestisida (kontrol) dan fungisida kimia. Meskipun tidak berbeda nyata pada perlakuan biopestisida, perlakuan biopestisida Pfm001 dapat meningkatkan berat buah sehat pada cabai. 
Tabel 4. Rerata Berat Buah Sehat (g), Berat Buah Sakit Antraknosa (g), Berat Buah pertanaman (g)

\begin{tabular}{lccc}
\hline \multicolumn{1}{c}{ Perlakuan } & Berat Buah Sehat & Berat Buah Sakit & Berat Buah Pertanaman \\
\hline Penginduksi & & & \\
Tanpa penginduksi & $2794.0 \mathrm{p}$ & $5.937 \mathrm{p}$ & $2663.0 \mathrm{p}$ \\
Mirabilis jalapa & $3006.0 \mathrm{p}$ & $4.307 \mathrm{q}$ & $3050.5 \mathrm{p}$ \\
Amaranthus spinosus & $2884.0 \mathrm{p}$ & $4.498 \mathrm{q}$ & $2908.0 \mathrm{p}$ \\
Biopestisida & & & \\
Tanpa Biopestisida & $3087.8 \mathrm{a}$ & $6.303 \mathrm{a}$ & $3145.4 \mathrm{a}$ \\
Bio Amp & $2934.4 \mathrm{a}$ & $4.258 \mathrm{~b}$ & $2986.0 \mathrm{a}$ \\
Bio Pfm001 & $2992.2 \mathrm{a}$ & $5.314 \mathrm{ab}$ & $2728.3 \mathrm{a}$ \\
BioAmp+Pfm & $2902.2 \mathrm{a}$ & $4.734 \mathrm{~b}$ & $2927.9 \mathrm{a}$ \\
Fungisida kimia & $2556.7 \mathrm{a}$ & $3.961 \mathrm{~b}$ & $2581.4 \mathrm{a}$ \\
\hline Interaksi & - & \multicolumn{1}{c}{ - } \\
\hline Keterangan: Angka yang diikuti huruf pada kolom yang sama tidak berbeda nyata menurut \\
uji DMRT pada taraf $\alpha$ 5\%. Tanda (-) menunjukkan tidak ada interaksi.
\end{tabular}

Kemampuan penginduksi resistensi Mirabilis jalapa dan Amaranthus spinosus dapat menekan berat buah sakit akibat antraknosa. Mekanisme resistensi tanaman terinduksi ternyata dapat mempengauhi dalam perkembangan cendawan Collethotricum capsici pada cabai. Demikian juga dengan biopestisida yaitu biopestisida Amp dan kombinasi kedua biopestisida (Amp+Pfm001) memberikan hasil yang nyata dalam menekan berat buah sakit akibat penyakit antraknosa dengan hasil yang tidak berbeda nyata dengan pembanding yaitu benzothiadiazole+Mankozeb yang ada pada fungisida kimia, hal ini diduga bahwa gadung (Dioscorea sp) dengan kandungan bahan aktif yaitu diosgenin, saponin, dioskorin dan bakteri Pseudomonas fluorescence pada Pfm001, efektif dalam menekan perkembangan serangan penyakit antraknosa pada buah cabai sehingga berpengaruh terhadap rendahnya berat buah sakit yang didapatkan.

Peran penginduksi resistensi dan biopestisida dalam meningkatkan jumlah buah sehat yang ditunjukkan pada tabel 5 tidak berpengaruh nyata. Hal ini dimungkinkan bahwa varietas tanaman cabai tersebut adalah varietas tanaman cabai yang dapat menghasilkan buah cabai yang banyak sehingga pengaruh dari penginduksi resistensi dan biopestisida kurang banyak berperan.
Tabel 5. Rerata Jumlah Buah Sehat, Jumlah Buah Sakit Antraknosa, Hasil (ton/ha)

\begin{tabular}{|c|c|c|c|}
\hline Perlakuan & Berat Buah Sehat & Berat Buah Sakit & Berat Buah Pertanaman \\
\hline \multicolumn{4}{|l|}{ Penginduksi } \\
\hline Tanpa penginduksi & $2794.0 p$ & $5.937 p$ & $2663.0 p$ \\
\hline Mirabilis jalapa & $3006.0 p$ & $4.307 q$ & $3050.5 p$ \\
\hline Amaranthus spinosus & $2884.0 p$ & $4.498 q$ & $2908.0 p$ \\
\hline \multicolumn{4}{|l|}{ Biopestisida } \\
\hline Tanpa Biopestisida & $3087.8 \mathrm{a}$ & $6.303 \mathrm{a}$ & $3145.4 \mathrm{a}$ \\
\hline Bio Amp & $2934.4 \mathrm{a}$ & $4.258 b$ & $2986.0 \mathrm{a}$ \\
\hline Bio Pfm001 & $2992.2 \mathrm{a}$ & $5.314 a b$ & $2728.3 a$ \\
\hline BioAmp+Pfm & $2902.2 \mathrm{a}$ & $4.734 \mathrm{~b}$ & $2927.9 \mathrm{a}$ \\
\hline Fungisida kimia & $2556.7 \mathrm{a}$ & $3.961 \mathrm{~b}$ & $2581.4 \mathrm{a}$ \\
\hline Interaksi & - & - & - \\
\hline
\end{tabular}

Pemberian perlakuan penginduksi resistensi yaitu Mirabilis jalapa dan Amaranthus spinosus berpengaruh nyata terhadap jumlah buah sakit bila dibandingkan dengan pemberian perlakuan non penginduksi resistensi. Hal ini menunjukkan bahwa ekstrak Mirabilis jalapa dan Amaranthus spinosus dapat menekan jumlah buah sakit pada tanaman cabai akibat serangan antraknosa. Tetapi tidak dengan parameter hasil yang didapatkan, kedua perlakuan pengiduksi resistensi tersebut tidak memberikan pengaruh yang nyata dalam meningkatkan hasil cabai.

Perlakuan biopestisida Amp, biopestisida Amp+Pfm001 tidak berbeda nyata dengan perlakuan non biopestisida dan biopestisida Pfm001. Hasil perlakuan Amp nyata lebih tinggi dari perlakuan fungisida kimia. Tingginya hasil tanaman yang diperlakukan dengan biopestisida Amp diduga bahwa senyawa yang terkandung dalam biopestisida tersebut yaitu dioskorin, diosgenin dapat meningkatkan hasil tanaman cabai yang lebih tinggi dibanding penggunaan Benzothiadiazole pada fungisida kimia.

Perlakuan biopestisida Pfm001 dan fungisida kimia ternyata lebih rendah pada hasil yang didapat bila dibanding dengan perlakuan non biopestisida. Hal ini diduga bahwa komponen hasil yang didapatkan banyak sakit, dimung- 
kinkan akibat terserang penyakit antraknosa, rusak akibat hama, dan akibat akumulasi residu kimia yang dapat menyebabkan menurunkan berat buah pada petak hasil. Selain itu juga dimungkinkan akibat serangga yang berguna dalam penyerbukan ikut mati akibat adanya pemberian pestisida sehingga berpengaruh terhadap penyerbukan yang berlangsung. Sedangkan pada perlakuan non biopestisida didapatkan nilai tertinggi pada hasil. Hal ini dipengaruhi oleh penyerbukan yang dibantu oleh adanya peran dari serangga dan faktor lingkungan seperti angin.

Efektifitas berbagai fitoaleksin atau senyawa bioaktif dan glikoprotein yang kaya dengan hidroksiprolin (HRGP) pada tanaman yang terinduksi oleh biopestisida dan juga Mirabilis jalapa sebagai reaksi atas ekspresi gen pertahanan yang teraktifkan tersebut dapat meningkatkan hasil tanaman (Suganda, 2000).

\section{SIMPULAN}

Berdasarkan hasil analisis dan pembahasan di atas maka dapat disimpulkan bahwa penginduksi resistensi dapat menekan buah cabai terserang antraknosa tetapi tidak berpengaruh dalam menekan penyakit bercak daun Cercospora, tidak mempengaruhi pertumbuhan tanaman tetapi dapat menekan jumlah buah sakit dan berat buah sakit.serta menekan antraknosa pada buah cabai. Biopestisida tidak berpengaruh terhadap penyakit bercak daun Cercospora tetapi menurunkan Antraknosa pada buah cabai. Biopestisida tidak berpengaruh terhadap pertumbuhan tanaman cabai tetapi dapat menurunkan jumlah buah sakit dan berat buah sakit serta dapat meningkatkan hasil. Tidak terdapat interaksi antara penginduksi resistensiresistensi dan biopestisida terhadap semua parameter kecuali terhadap parameter Area Under Desease Progress Curve (AUDPC).
Perlu dilakukan penelitian lanjutan dengan menggunakan bahan biopestisida (Dioscorea sp dan Pseudomonas fluorescence) dengan konsentrasi yang lebih banyak sehingga lebih toksik dalam menekan serangan cendawan pada cabai dan lebih jelas terlihat perbedaannya. Perlu dilakukan penelitian lanjutan tentang kemungkinan aplikasi penginduksi resistensiresistensi dan biopestisida pada saat awal pertumbuhan (fase vegetatif) maupun pada awal fase generatif tanaman cabai.

\section{DAFTAR PUSTAKA}

Adiyoga, W., dan Thomas Agus Soetiarso.1995. Aspek Agroekonomi Cabai dalam Agribisnis Cabai.Panebar Swadaya.Jakarta. p:36 - 52.

BPS. 2000.Produksi Tanaman Sayuran dan Buah-buahan. Badan Pusat Statistik. Jakarta. 2002.Produksi Tanaman Sayuran dan Buah-buahan. Badan Pusat Statistik. Jakarta. .2003.Produksi Tanaman Sayuran dan Buah-buahan. Badan Pusat Statistik. Jakarta.

Gomez, K.A. dan Arturo A. Gomez.1995. Prosedur Statistik Untuk Penulisan Pertanian. Edisi kedua.Universitas Indonesia Press. Jakarta.

Hadisutrisno, Bambang.1999.Peranan Faktor Lingkungan Terhadap Penyakit Antraknos pada Bawang Merah.Jurnal Perlindungan Tanaman Indonesia V (1) p: 20 - 23.

Hersanti, Ceppy Nasahi, dan Toto Sunarto.2003.Pengujian Beberapa Ekstrak Tumbuhan Sebagai Agen Penginduksi resistensiKetahanan Sistemik Tanaman Cabai Merah Terhadap Cucumber Mozaik Virus (CMV). Jurnal Agrikultura (14)/3. p: 160-165.

Indratmi, Dian.2002.Pengujian Potensi Yeast like-fungi Schizosaccharomyces sp untuk Pengendalian Colletotrichum gloeosporoides pada Tanaman Cabai.Tropika X(2) : 127-137.

Indrawati A., Andi K.R., Ani K., Edy S., I Wayan L., Muhammad Syakir, Muhammad Taufik, Noor A, Trizelia, Ujang K., Zulyusri.2001.Konservasi Agens Hayati Organisme Pengganggu Tanaman. Makalah Mahasiswa Program Pasca Sarjana IPB. Bogor.

Martanto, Eko Agus., Cristanti Sumardiyono, Haryono Semangun, Bambang Hadi Sutrisno.2003. Peranan Asam Salisilat Pada Interaksi Inang-Patogen Penyakit Kudis Ubijalar (Elsinoe batatas). Jurnal Perlindungan Tanaman Indonesia (9)/2. p: 92-98.

Oka, Ida Bagus.2001.Induced Systemic Resistance to Cercospora capsici Heald \& Wolf, Fusarium oxysporum Schlecht. F.sp vasinvectum Snyder \& Hans., and Colletotricum gloeosporoiodes (Penz.) Sacc. On Hot Pepper (Capsicum anuum L.) by Inoculation of Rhizopseudomonas. Disertasi. Program Pasca Sarjana Universitas Padjadjaran.Bandung. (Tidak Dipublikasikan). 
114 Planta Tropika Journal of Agro Science Vol. 2 No. 2 / Agustus 2014

Rosmana, Ade., Sylvia S., Alias dan Sjamsir.1997.Evaluasi Penggunaan Nematoda Entomopatogen Steinema carcocapse Isolat Sulawesi Selatan sebagai Biosida untuk Mengendalikan Hama Kubis Crocidolomia binotalis.Prosiding Seminar Perhimpunan Bioteknologi Pertanian Indonesia.Surabaya. p: $379-385$.

Soesanto, Loekas.2002.Pemanfaatan Agensia Hayati dalam Mewujudkan Keseimbangan Ekosistem Pertanian.Jagad Vol (1)/1.Purwokerto.

Suganda, T.1999.Imunisasi Tanaman : Perspektif Baru Untuk Melindungi Tanaman dari Serangan Penyakit. Jurnal Bionatura (1)/l, p: $46-60$.

; Endah. R; Endah Yulia dan Ceppy Nasahi. 2002.

Pengujian Kemampuan Beberapa Bahan Kimia da Air Perasan Daun Tumbuhan dalam Menginduksi Resistensi Tanaman Padi Terhadap Penyakit Bercak Daun Cercospora. Jurnal Bionatura (4)/1. p : 17-28.

Suwahyono, Untung., Priyo Wahyudi.1997. Proteksi Tanaman Alpukat dari Serangan Jamur Tular Tanah dengan Menggunakan Biofungisida Tricoderma harzianum. Prosiding Perhimpunan Bioteknologi Pertanian Indonesia. Surabaya. p: 316 - 326.

Untung, Kasumbogo.1993.Pengantar Pengelolaan Hama Terpadu.Gajah Mada University Press.Jogjakarta

Vos, J G M. 1994. Pengelolaan Tanaman Terpadu pada Cabai di Dataran Rendah Tropis terjemahan Disertasi : Integrated Crop Management of Hot Pepper (Capsicuum anuum) in Tropical Lowlands.Bentang. 